\author{
WITOLD MAŁECKI \\ ORCID: 0000-0002-8819-0317 \\ Uniwersytet Wrocławski \\ witold.malecki@uwr.edu.pl
}

\title{
Samoregulacja działalności gospodarczej i zawodowej. Organizacje samoregulacyjne w prawie rosyjskim
}

\begin{abstract}
Abstrakt: Samoregulacja działalności gospodarczej i zawodowej polega na tworzeniu i kontrolowaniu przestrzegania norm kształtujących sposób wykonywania danej działalności przez podmioty prowadzące tę działalność. W prawie rosyjskim samoregulacja realizowana jest przede wszystkim w ramach funkcjonowania organizacji samoregulacyjnych zrzeszających podmioty określonej działalności gospodarczej lub zawodowej. Organizacje samoregulacyjne funkcjonują jako organizacje o dobrowolnym członkostwie oraz organizacje o obowiązkowym członkostwie. W określonych dziedzinach działalności gospodarczej i zawodowej uzyskanie członkostwa w organizacji samoregulacyjnej, uwarunkowane spełnieniem pewnych przesłanek, stanowi prawny wymóg podjęcia danej działalności. Z tej przyczyny organizacje samoregulacyjne o obowiązkowym członkostwie należy uznać za korporacje prawa publicznego. Publicznoprawne znamię tych organizacji odznacza się charakterem transcendentnym, z uwagi na oddolny sposób ich tworzenia.
\end{abstract}

Słowa kluczowe: działalność gospodarcza, działalność zawodowa, samoregulacja, organizacja samoregulacyjna, prawo rosyjskie.

\section{Wprowadzenie}

We współczesnych ustawodawstwach gospodarczych coraz wyraźniej dostrzegalna jest tendencja do odstępowania od tradycyjnego paradygmatu regulacji działalności gospodarczej, zakładającego wyznaczanie położenia prawnego podmiotów działalności gospodarczej (przedsiębiorców) za pomocą ustanawianych przez prawodawcę norm zawierających nakazy i zakazy określonych zachowań. W wielu systemach prawnych przedsiębiorcy nie są już postrzegani wyłącznie jako obiekty 
władczego oddziaływania organów władzy publicznej, lecz także jako podmioty aktywnie uczestniczące w kształtowaniu ładu gospodarczego, również w perspektywie prawnej. W polskim porządku prawnym zasadniczą regulacją wyznaczającą ramy współdziałania organów władzy publicznej i przedsiębiorców w sferze gospodarki jest art. 20 Konstytucji RP, zgodnie z którym solidarność, dialog i współpraca partnerów społecznych stanowią jeden z filarów społecznej gospodarki rynkowej, będącej podstawą ustroju gospodarczego Rzeczypospolitej Polskiej. Państwo winno zatem zapewnić przedsiębiorcom - jako partnerom społecznym ${ }^{1}$ - możliwość czynnego udziału w kształtowaniu prawnych ram funkcjonowania gospodarki rynkowej ${ }^{2}$. Co więcej, za odzwierciedlenie „partnerskiego” traktowania przedsiębiorców należy uznać posługiwanie się przez prawodawcę (w obrębie regulacji prawa gospodarczego) adresowanymi do nich normami promującymi i normami rekomendującymi. Nie zawierają one nakazów i zakazów, lecz obejmują pewne bodźce zachęcające przedsiębiorców do podejmowania działań korzystnych z perspektywy interesu publicznego oraz niewiążące zalecenia mające na celu wskazanie przedsiębiorcom pewnego efektywnego sposobu osiągnięcia pożądanych stanów i dóbr ${ }^{3}$.

$\mathrm{Na}$ gruncie rosyjskiego porządku prawnego za instytucję prawną, która stanowi wyraz dopuszczenia przedsiębiorców do (współ)tworzenia prawnego środowiska wykonywania działalności gospodarczej, należy z pewnością uznać „samoregulację" (samoregulirowanije). Pojęcie „samoregulacji” zostało objęte definicją legalną, zawartą w art. 2 ust. 1 ustawy federalnej z dnia 1 grudnia 2007 roku o organizacjach samoregulacyjnych (dalej: u.o.s.) ${ }^{4}$. Zgodnie z tą definicją samoregulacja oznacza samodzielną i inicjatywną działalność realizowaną przez podmioty działalności gospodarczej lub zawodowej, której istotą jest opracowywanie i ustanawianie norm i zasad wykonywania określonej działalności oraz kontrola przestrzegania tych norm i zasad. Artykuł 2 ust. 2 u.o.s. stanowi, że samoregulacja normowana tą ustawą odbywa się w ramach zrzeszenia podmiotów działalności gospodarczej lub zawodowej w organizacjach samoregulacyjnych. W niniejszym artykule przedstawione zostaną zasadnicze elementy tożsamości prawnej instytucji samoregulacji oraz statusu prawnego organizacji samoregulacyjnych, z uwzględnieniem problemu przypisania im charakteru publicznoprawnego bądź prywatnoprawnego.

1 O pojęciu partnerów społecznych zob. m.in. A. Domańska, Konstytucyjne podstawy ustroju gospodarczego Polski, Warszawa 2001, s. 131.

2 B. Banaszak, Prawo konstytucyjne, Warszawa 2008, s. 256.

3 Szerzej zob. W. Małecki, Metoda promocji jako typ metody regulacji, „Prawo” 323, 2017, s. 253-261; idem, Policja gospodarcza w prawie gospodarczym, Warszawa 2019, s. 182-218.

4 Federal'nyj zakon ot 01.12.2007 N 315-FZ ,, O samoreguliruemyh organizaciâh”. 


\section{Istota samoregulacji działalności gospodarczej i zawodowej}

Wprowadzenie do prawa rosyjskiego instytucji samoregulacji doprowadziło do zarysowania się dwóch różnych sfer regulacji działalności gospodarczej - regulacji państwowej oraz samoregulacji. W obu sferach kreowane są normy adresowane do przedsiębiorców, wyznaczające warunki podejmowania i wykonywania działalności gospodarczej. Tym niemniej, obie sfery odznaczają się zasadniczymi odmiennościami. Podstawowa różnica, stanowiąca o istocie obu sfer regulacji, mieści się oczywiście na płaszczyźnie podmiotowej. W obrębie regulacji państwowej ustanawianiem norm zajmują się właściwe organy władzy publicznej, podczas gdy w obrębie samoregulacji normy są kreowane przez organizacje samoregulacyjne. Wyodrębnić należy także przedmiotową płaszczyznę odmienności, która odnosi się do różnej treści norm — według Dmitrija Olegowicza Graczowa nie może być mowy o samoregulacji w sytuacji, gdy organizacje samoregulacyjne powielają normy wynikające z przepisów ustanawianych przez organy władzy publicznej ${ }^{5}$. Samoregulacja obejmuje bowiem te normy, które organizacje samoregulacyjne tworzą niezależnie od norm należących do regulacji państwowej, przy czym — rzecz jasna — nie mogą być z tymi normami sprzeczne. Odmiennie kształtują się także sankcje z tytułu nieprzestrzegania norm sytuujących się w sferach regulacji państwowej i samoregulacji. O ile w rezultacie naruszania norm należących do pierwszej ze sfer zastosowanie mogą znaleźć sankcje administracyjne i karne, o tyle postępowanie sprzeczne z normami kreowanymi w sferze samoregulacji może skutkować sankcjami przewidzianymi $\mathrm{w}$ obrębie danej organizacji samoregulacyjnej, w tym także wykluczeniem z organizacji. Takie konsekwencje mogą się $\mathrm{w}$ pewnych sytuacjach wiązać $\mathrm{z}$ utratą prawa do wykonywania określonej działalności ${ }^{6}$.

Problemem rozważanym w doktrynie jest wzajemna relacja między obiema sferami regulacji działalności gospodarczej. Julia Giennadiewna Leskowa wyróżnia dwie możliwe perspektywy postrzegania tej relacji. W pierwszej z nich samoregulacja przedstawia się jako „przedłużenie” regulacji państwowej, podczas gdy na gruncie drugiej samoregulację należy uznać za przeciwstawną wobec regulacji państwowej ${ }^{7}$. W pierwszą perspektywę wpisuje się stanowisko Stanisława Akimowicza Zinczenki i Wiktora Władimirowicza Gałowa, według których organizacje samoregulacyjne realizują prawotwórcze funkcje państwa, w ramach pry-

5 D.O. Gračev, Pravila samoreguliruemyh organizacji, ,Zakony Rossii. Opyt, analiz, praktika" 2009, nr 2, s. 17.

${ }^{6}$ P.B. Salin, Stanovlenie i razvitie instituta samoreguliruemoj organizacii v Rossijskoj Federacii (teoretiko-pravovoe issledovanie), Petersburg 2009, s. 25.

7 Û.G. Leskova, Konceptual'nye i pravovye osnovy samoregulirovaniâ predprinimatel'skih otnošenij, Moskwa 2013, s. 23. 
watyzacji wykonywania funkcji państwa. Powierzenie funkcji prawotwórczych organizacjom samoregulacyjnym jest uwarunkowane dążeniem do stworzenia unormowań o wysokim stopniu efektywności, czemu sprzyja ta okoliczność, że organizacje samoregulacyjne (jako zrzeszenia przedsiębiorców wykonujących określony rodzaj działalności gospodarczej) dysponują wyższymi niż państwowy prawodawca kompetencjami merytorycznymi do ustanawiania norm odpowiadających specyfice danego rodzaju działalności ${ }^{8}$. Do drugiej perspektywy nawiązują natomiast poglądy Graczowa i Piotra Michajłowicza Łanskowa, którzy podkreślają, że samoregulacja ma charakter samodzielny i autonomiczny, w związku z czym organizacje samoregulacyjne - jako podmioty normotwórcze - działają we własnym imieniu, a kreowane przez nie normy stanowią wyraz własnej i swobodnej (w granicach prawa) aktywności normotwórczej. Ona zaś nie musi być rozwinięciem regulacji ustanawianych przez organy władzy publicznej ${ }^{9}$.

$\mathrm{W}$ odniesieniu do przywołanego powyżej problemu wzajemnego stosunku regulacji państwowej i samoregulacji wydaje się, że in abstracto najwłaściwsze jest pośrednie stanowisko sformułowane przez Innę Władimirownę Jerszową. Autorka ta obrazuje regulację państwową i samoregulację jako odrębne ogniwa tego samego łańcucha oddziaływania na sytuację prawną przedsiębiorców. Jakkolwiek są to sfery regulacji względem siebie autonomiczne, nie sposób uznać ich za przeciwstawne sobie - powinny one bowiem uzupełniać się tak, by wspólnie tworzyć spójny system regulacji działalności gospodarczej, w którym dla pewnych zagadnień właściwsza (bardziej efektywna) będzie regulacja państwowa, a dla innych zagadnień - samoregulacja ${ }^{10}$. In concreto, spojrzenie na problem wzajemnego stosunku regulacji państwowej i samoregulacji wymaga uwzględnienia odmiennego charakteru samoregulacji realizowanej $\mathrm{w}$ ramach organizacji samoregulacyjnych o dobrowolnym i obowiązkowym członkostwie, co stanie się przedmiotem rozważań w dalszej części niniejszego opracowania.

Warto zaznaczyć, że dopuszczalność funkcjonowania w rosyjskim systemie prawa instytucji samoregulacji stała się przedmiotem rozstrzygnięć Sądu Konstytucyjnego Federacji Rosyjskiej. Przykładowo, w postanowieniu z dnia 19 grudnia 2005 roku, Sąd Konstytucyjny podkreślił, że instytucja samoregulacji wpisuje się w konstytucyjne zasady demokratycznego państwa prawnego i swobody działalności gospodarczej, stanowiąc wyraz dążenia do urzeczywistnienia założeń samorządności i autonomiczności podmiotów działalności gospodarczej, a przez to sprzyjając także ukształtowaniu się w państwie społeczeństwa obywatelskiego. Sąd zaznaczył również, że normy ustanawiane w sferze samoregulacji nie pozo-

${ }^{8}$ S.A. Zinčenko, V.V. Galov, Samoreguliruemye organizacii v zakonodatel'stve Rossii: problemy i rešeniâ, [w:] Korporacii i učreždeniâ, red. M.A. Rožkova, Moskwa 2007, s. 98-99.

9 D.O. Gračev, Pravovoj status samoreguliruemyh organizacij, Moskwa 2008, s. 54; P.M. Lanskov, Mehanizm regulirovaniâ finansovogo rynka i ego infrastruktury, Moskwa 2005, s. 185.

10 I.V. Eršova, Samoregulirovanie predprinimatel'skoj deâtel'nosti, [w:] Predprinimatel'skoe pravo, red. I.V. Eršova, Moskwa 2017, s. 434. 
stają poza zakresem zainteresowania organów władzy publicznej, albowiem organy władzy publicznej mogą w różny sposób oddziaływać na te normy, między innymi w ramach sądowej kontroli zgodności z prawem treści norm ${ }^{11}$.

\section{Status prawny organizacji samoregulacyjnych}

Definicja legalna organizacji samoregulacyjnych została zawarta w art. 3 ust. 1 u.o.s. Zgodnie z tym przepisem organizacje samoregulacyjne to organizacje non-profit utworzone w celach określonych przez ustawy, oparte na członkostwie, zrzeszające podmioty działalności gospodarczej funkcjonujące w tej samej gałęzi wytwórstwa towarów (robót, usług) lub na tym samym rynku wytwarzanych towarów (robót, usług), lub też zrzeszające podmioty działalności zawodowej określonego rodzaju. $Z$ powyższej definicji wynika, że organizacje samoregulacyjne stanowią szczególną kategorię organizacji non-profit, których ogólną tożsamość prawną wyznaczają przepisy części pierwszej Kodeksu cywilnego ${ }^{12}$ oraz ustawy federalnej z dnia 12 stycznia 1996 roku o organizacjach non-profit ${ }^{13}$. Warto zaznaczyć, że według art. 50 ust. 1 Kodeksu cywilnego osoby prawne dzielą się na dwie podstawowe kategorie - organizacje handlowe (kommierczeskije organizacii) i organizacje non-profit (niekommierczeskije organizacii), które odróżnia dążenie (lub nie) do osiągania zysku jako podstawowy cel działania organizacji. W art. 50 ust. 2 i 3 Kodeksu cywilnego wyliczono rodzaje osób prawnych zaliczanych do organizacji handlowych i organizacji non-profit — zgodnie z art. 50 ust. 3 pkt 3 organizacje samoregulacyjne funkcjonują jako stowarzyszenia/związki (assocyacii/sojuzy), będące — obok, między innymi, organizacji społecznych czy spółdzielni konsumenckich — jedną z form prawnych organizacji non-profit.

Ogólny reżim prawny funkcjonowania stowarzyszeń konstytuują — jak wspomniano - Kodeks cywilny oraz ustawa o organizacjach non-profit. Przepisy ustawy o organizacjach samoregulacyjnych wprowadzają jednak szczególne unormowania znajdujące zastosowanie do organizacji samoregulacyjnych jako wyodrębnionego rodzaju stowarzyszeń/związków. Artykuł 3 ust. 3 u.o.s. wskazuje trzy warunki, które powinna spełniać organizacja samoregulacyjna. Po pierwsze, organizacja taka powinna zrzeszać nie mniej niż 25 podmiotów działalności gospodarczej lub 100 podmiotów działalności zawodowej ${ }^{14}$. Po drugie, w ramach organizacji powinny funkcjonować normy i zasady wykonywania działalności

11 Postanowienie Sądu Konstytucyjnego Federacji Rosyjskiej z dnia 19 grudnia 2005 roku, nr 12-P.

12 Graždanskij kodeks Rossijskoj Federacii (čast' pervaâ) ot 30.11.1994 N 51-FZ.

13 Federal'nyj zakon ot 12.01.1996 N 7-FZ „O nekommerčeskih organizaciâh”.

14 Zgodnie z art. 15 ust. 1.3 a contrario ustawy o organizacjach non-profit stowarzyszenie/ związek co do zasady może zostać założone przez co najmniej dwie osoby. 
gospodarczej i zawodowej, których spełnienie jest obowiązkowe dla wszystkich członków organizacji. Po trzecie, organizacja samoregulacyjna musi zapewniać każdemu ze swoich członków dodatkową odpowiedzialność majątkową z tytułu kierowanych przeciwko nim roszczeń, przy czym w myśl art. 13 ust. 1 u.o.s. dodatkowa odpowiedzialność majątkowa może zostać zapewniona poprzez zagwarantowanie indywidualnego lub zbiorowego ubezpieczenia albo utworzenie funduszu kompensacyjnego. Ponadto, w art. 16 i art. 19 u.o.s. określono organy, które muszą funkcjonować w organizacji samoregulacyjnej — należą do nich: ogólne zgromadzenie członków organizacji, kolegialny organ zarządzania organizacją, organ wykonawczy organizacji, organ sprawujący kontrolę nad przestrzeganiem przez członków organizacji funkcjonujących w niej norm i zasad wykonywania działalności oraz organ właściwy w zakresie rozpoznawania spraw dotyczących odpowiedzialności dyscyplinarnej członków organizacji. Szczególny status organizacji samoregulacyjnych jako wyodrębnionej kategorii organizacji non-profit odzwierciedla obowiązek ich podwójnej rejestracji. Po pierwsze, zgodnie z art. 13 ust. 1 ustawy o organizacjach non-profit wszystkie organizacje non-profit - w tym także „przyszłe” organizacje samoregulacyjne — podlegają rejestracji w Jednolitym Państwowym Rejestrze Osób Prawnych. Po drugie, według art. 3 ust. 6 u.o.s. organizacja non-profit (już zarejestrowana w Jednolitym Państwowym Rejestrze Państwowych Osób Prawnych) nabywa status organizacji samoregulacyjnej z chwilą wpisania jej do rejestru organizacji samoregulacyjnych.

Należy zaznaczyć, że przedstawione powyżej prawne warunki funkcjonowania i ustroju organizacji samoregulacyjnych, wynikające z ustawy o organizacjach samoregulacyjnych, są niekiedy odmiennie ujmowane w aktach prawnych dotyczących organizacji samoregulacyjnych zrzeszających podmioty działalności gospodarczej lub zawodowej w określonych dziedzinach. Wśród tych aktów prawnych wypada wspomnieć przede wszystkim o ustawie federalnej z dnia 13 lipca 2005 roku o organizacjach samoregulacyjnych w sferze rynku finansowego ${ }^{15}$, odnoszącej się do organizacji zrzeszających podmioty wykonujące działalność w siedemnastu dziedzinach, określonych w art. 3 ust. 1 tej ustawy; są to między innymi działalność brokerska, działalność ubezpieczeniowa czy też prowadzenie niepaństwowych funduszy emerytalnych. Wśród odrębności wynikających z przepisów tej ustawy - na tle ogólnych unormowań wynikających z ustawy o organizacjach samoregulacyjnych można przykładowo wspomnieć o odmiennym określeniu minimalnej liczby członków organizacji. Zgodnie z art. 3 ust. 4 pkt 1 ustawy o organizacjach samoregulacyjnych w sferze rynku finansowego organizacja powinna zrzeszać co najmniej $26 \%$ łącznej liczby podmiotów wykonujących dany rodzaj działalności. Innym przykładem odmiennego określenia minimalnej liczby członków organizacji jest unormowanie zawarte w art. 55.4 ust. 1 pkt 1 Kodeksu

15 Federal'nyj zakon ot 13.07.2015 N 223-FZ „O samoreguliruemyh organizaciâh v sfere finansovogo rynka". 
urbanistycznego ${ }^{16}$, zgodnie z którym organizacje samoregulacyjne funkcjonujące w sferze prowadzenia prac inżynieryjnych oraz przygotowywania dokumentacji projektowej powinny zrzeszać nie mniej niż 50 przedsiębiorców prowadzących działalność w tych dziedzinach.

Powyższe odmienności odzwierciedlają zdecentralizowany charakter prawnego unormowania organizacji samoregulacyjnych - jakkolwiek ustawa o organizacjach samoregulacyjnych zawiera przepisy o charakterze ogólnym, co do zasady wspólne dla wszystkich organizacji, to jednak ustawy szczegółowe zawierają znaczną liczbę przepisów odmiennie normujących pewne aspekty funkcjonowania i ustroju organizacji samoregulacyjnych działających w określonych dziedzinach gospodarki. Zjawisko dezintegracji prawnego unormowania organizacji samoregulacyjnych według Jerszowej nie powinno jednak podlegać negatywnej ocenie; specyfika poszczególnych dziedzin działalności gospodarczej i zawodowej sprawia, że dyferencjacja reżimu prawnego funkcjonowania organizacji samoregulacyjnych wydaje się w wielu przypadkach uzasadniona i konieczna ${ }^{17}$.

\section{Organizacje samoregulacyjne o dobrowolnym i obowiązkowym członkostwie}

Analiza statusu prawnego organizacji samoregulacyjnych wymaga uwzględnienia ich dychotomicznego podziału, w ramach którego wyróżnieniu podlegają organizacje o dobrowolnym członkostwie i organizacje o obowiązkowym członkostwie. Zgodnie z art. 5 ust. 1 u.o.s. członkostwo podmiotów działalności gospodarczej lub zawodowej w organizacjach samoregulacyjnych jest dobrowolne - a zatem podjęcie decyzji o ubieganiu się o przystąpienie do organizacji stanowi przedmiot swobodnego uznania podmiotu działalności gospodarczej lub zawodowej. Podjęcie tej decyzji jest uwarunkowane przesłankami o charakterze nie prawnym, lecz ekonomicznym, jak choćby dążeniem do podwyższenia jakości produkowanych lub oferowanych towarów lub usług w rezultacie zastosowania norm i zasad obowiązujących $\mathrm{w}$ organizacji ${ }^{18}$; zamiarem uzyskania przez przedsiębiorcę lepszej renomy jako członka organizacji stosującej dodatkowe (to jest niewynikające z regulacji państwowej) warunki wykonywania działalności gospodarczej; chęcią zapewnienia sobie szerszej ochrony przed odpowiedzialnością majątkową poprzez fundusz kompensacyjny lub ubezpieczenie zapewniane przez organizację samoregulacyjną.

\footnotetext{
16 Gradostroitel'nyj kodeks Rossijskoj Federacii ot 29.12.2004 N 190-FZ.

17 I.V. Eršova, Samoregulirovanie..., s. 432.

18 Zob. Û.G. Leskova, Konceptual'nye i pravovye osnovy..., s. 152.
} 
Do organizacji samoregulacyjnych o obowiązkowym członkostwie odnosi się art. 5 ust. 2 u.o.s., według którego ustawa federalna może przewidywać obowiązek członkostwa podmiotów działalności gospodarczej i zawodowej w organizacji samoregulacyjnej. W takich okolicznościach uzyskanie członkostwa $\mathrm{w}$ organizacji samoregulacyjnej stanowi warunek podjęcia określonej działalności gospodarczej lub zawodowej. W obecnie obowiązującym ustawodawstwie rosyjskim uzyskania członkostwa w organizacji samoregulacyjnej wymaga podjęcie działalności gospodarczej lub zawodowej w dwunastu dziedzinach. Są to: działalność rzeczoznawców, działalność syndyków, działalność biegłych rewidentów, działalność aktuariuszy, działalność związków rewizyjnych spółdzielni rolniczych, działalność w dziedzinie organizowania gier hazardowych, działalność inżynierów katastralnych, działalność operatorów platform elektronicznych, działalność w dziedzinie prowadzenia badań (prac) energetycznych, działalność w dziedzinie robót budowlanych, działalność w dziedzinie prowadzenia prac inżynieryjnych oraz działalność w dziedzinie przygotowywania dokumentacji projektowej ${ }^{19}$. Ustawodawca, zobowiązując podmioty zainteresowane podjęciem określonej działalności do uzyskania członkostwa w organizacji samoregulacyjnej, wskazuje zarazem warunki, których spełnienie jest konieczne dla uzyskania tego członkostwa. Przykładowo, zgodnie z art. 20 ust. 1 i ust. 9 ustawy federalnej z dnia 26 października 2002 roku o niewypłacalności (bankructwie ${ }^{20}$ podjęcie działalności syndyka (arbitrażnyj uprawlajuszczij) wymaga przyjęcia do organizacji samoregulacyjnej syndyków. Przepisy art. 20 ust. 2 i 3 powołanej ustawy stanowią natomiast, że organizacja samoregulacyjna syndyków określa obligatoryjne warunki członkostwa w postaci: posiadania wyższego wykształcenia, legitymowania się odpowiednim doświadczeniem zawodowym, uzyskania pozytywnego wyniku z egzaminu dla kandydatów na syndyków, braku karalności za określone kategorie przestępstw, braku wcześniejszego wykluczenia z organizacji samoregulacyjnej syndyków oraz posiadania odpowiedniego ubezpieczenia. Wyznaczone ustawą warunki członkostwa w organizacji mają jednak charakter warunków minimalnych — art. 20 ust. 4 ustawy upoważnia bowiem organizację samoregulacyjną do ustanowienia także innych, dodatkowych warunków członkostwa w tej organizacji.

Zarysowanie podziału organizacji samoregulacyjnych na organizacje o dobrowolnym i obowiązkowym członkostwie pozwala ponownie odnieść się do wspomnianego we wcześniejszej części niniejszego tekstu problemu wzajemnego stosunku regulacji państwowej i samoregulacji. Samoregulację, która następuje w ramach organizacji o obowiązkowym członkostwie, z pewnością można uznać

19 Za: Ministerstvo Èkonomičeskogo Razvitiâ Rossijskoj Federacii, O sostoânii razvitiâ samoregulirovaniâ predprinimatel'skoj i professional'noj deâtel'nosti v Rossijskoj Federacii, Moskwa 2019, s. 7. Pominięte zostały dziedziny działalności objęte ustawą o organizacjach samoregulacyjnych w sferze rynku finansowego, która ustanawia reżim prawny w wielu aspektach odmienny od ogólnego reżimu ukształtowanego ustawą o organizacjach samoregulacyjnych.

${ }^{20}$ Federal'nyj zakon ot 26.10.2002 N 127-FZ „O nesostoâtel'nosti (bankrotstve)”. 
za „przedłużenie” regulacji państwowej. W tej sytuacji państwo (prawodawca państwowy) postanawia, że podjęcie danego rodzaju działalności gospodarczej lub zawodowej będzie wymagało spełnienia określonych warunków (a zatem — według polskiej terminologii — określona dziedzina działalności stanie się reglamentowana), wyznacza także minimalne wymogi warunkujące dopuszczalność podjęcia tej działalności. Państwo „zdejmuje” jednak z siebie funkcję weryfikowania, czy podmiot zainteresowany podjęciem danej działalności spełnia właściwe wymogi, powierzając tę funkcję organizacjom samoregulacyjnym. Organizacje samoregulacyjne mogą także poszerzać katalog warunków podjęcia i wykonywania działalności, uzupełniając warunki wynikające z regulacji państwowej innymi, funkcjonującymi w obrębie danej organizacji. Samoregulacja realizowana przez organizacje samoregulacyjne o obowiązkowym członkostwie bywa w nauce określana samoregulacją delegowaną, która polega na przekazywaniu organizacjom samoregulacyjnym funkcji państwa w zakresie regulacji rynku i ograniczeniu roli państwa jedynie do wyznaczenia ogólnych, ramowych warunków i zasad wykonywania działalności danego rodzaju ${ }^{21}$. Przez wzgląd na powyższe okoliczności organizacje samoregulacyjne zostały w literaturze nazwane „kwalifikowanym przedstawicielem (kwalificirowannyj agent) państwa jako ogólnego regulatora" 22 .

Samoregulacja, która następuje w ramach organizacji samoregulacyjnych o dobrowolnym członkostwie, odznacza się natomiast wyraźnie autonomicznym charakterem względem regulacji państwowej. Ustanowienie warunków członkostwa w danej organizacji i obowiązujących w niej zasad prowadzenia określonej działalności następuje w rezultacie swobodnej decyzji podmiotów tworzących tę organizację i nie stanowi „wykonania” ani uzupełniania regulacji państwowej. Należy zaznaczyć, że samoregulacji w ramach organizacji o dobrowolnym członkostwie nie sposób jednak uznawać za zupełnie niezależną od regulacji państwowej — organizacje samoregulacyjne działają wszak w obrębie ogólnego reżimu prawnego funkcjonowania organizacji samoregulacyjnych, wyznaczonego przez prawodawcę państwowego, a także z uwzględnieniem innych powszechnie obowiązujących przepisów prawa państwowego 23 .

Analiza konstrukcji prawnej organizacji samoregulacyjnych o obowiązkowym członkostwie pozwala dostrzec $\mathrm{w}$ niej pierwiastki publicznoprawne. W pierwszej kolejności należy podkreślić, że organizacje o obowiązkowym członkostwie realizują działania o charakterze władczym, dopuszczając (lub nie) zainteresowane podmioty do wykonywania działalności gospodarczej lub zawodowej w dziedzi-

21 Û.G. Leskova, Konceptual'nye i pravovye osnovy..., s. 17.

22 A. Valitova, T. Uzbekov, Samoreguliruemye organizacii na rynke cennyh bumag: za i protiv obâzatel'nogo členstva, [w:] Problemy razvitiâ samoreguliruemyh organizacij v predprinimatel'skoj deâtel'nosti v Rossijskoj Federacii, red. A.È. Zaharova, Orenburg 2020, s. 26.

23 F.Û. Čatuev, Vzaimodejstvie gosudarstva i samoreguliruemyh organizacij na investicionnom rynke, Moskwa 2007, s. 41. 
nach, które - zgodnie z decyzją prawodawcy państwowego — nie są objęte sferą działalności wolnej, a zatem ich podjęcie wymaga spełnienia pewnych warunków. Organizacje o obowiązkowym członkostwie „wykonują” zatem decyzję prawodawcy państwowego o ograniczeniu dostępu do wykonywania danej działalności, uzasadnioną dążeniem do ochrony interesu publicznego. $Z$ tej przyczyny Leskowa nazywa organizacje samoregulacyjne o obowiązkowym członkostwie podmiotami prawa publicznego, które - realizując funkcje publicznoprawne urzeczywistniają interes państwa ${ }^{24}$. Pochodną zastosowanego przez rosyjskiego ustawodawcę modelu dopuszczania do wykonywania danej działalności za pomocą członkostwa w organizacjach samoregulacyjnych jest obligatoryjny charakter tego członkostwa, który należy postrzegać jako kolejny pierwiastek publicznoprawny w konstrukcji prawnej organizacji samoregulacyjnych o obowiązkowym członkostwie. Uwarunkowanie obowiązkowego członkostwa realizacją funkcji publicznoprawnych wprost podkreślił Sąd Konstytucyjny Federacji Rosyjskiej w przywoływanym już postanowieniu z dnia 19 grudnia 2005 roku, wskazując, że „wobec powierzenia organizacjom samoregulacyjnym syndyków funkcji publicznoprawnych do ich działalności nie znajduje zastosowania zasada dobrowolności wynikająca z art. 30 Konstytucji Federacji Rosyjskiej”; przepis ten stanowi, że nie można nikogo zmuszać do wstąpienia i pozostawania w jakiejkolwiek organizacji. O tożsamości i istocie funkcjonowania organizacji samoregulacyjnych o obowiązkowym członkostwie stanowi zatem ta okoliczność, że nie są one „zwykłymi” organizacjami opartymi na znamionującej sferę prawa prywatnego zasadzie dobrowolności członkostwa, lecz korporacjami prawa publicznego, wykonującymi funkcje publicznoprawne, których realizacja wymaga przydania członkostwu w nim znamienia obligatoryjności.

\section{Publicznoprawne znamię organizacji samoregulacyjnych o obowiązkowym członkostwie}

Konstrukcja prawna organizacji samoregulacyjnych o obowiązkowym członkostwie z pewnością wykazuje pewne podobieństwa do konstrukcji samorządu zawodowego, którego podmioty zrzeszają — na zasadzie członkostwa obligatoryjnego - podmioty wykonujące określony zawód. Na tle tradycyjnego modelu funkcjonowania samorządu zawodowego model działania organizacji samoregulacyjnych o obowiązkowym członkostwie odznacza się jednak pewną istotną odmiennością - o ile struktury organizacyjne samorządu zawodowego tworzone są odgórnie przez prawodawcę państwowego, o tyle organizacje samoregulacyjne powstają oddolnie, $\mathrm{z}$ wyłącznej inicjatywy podmiotów wykonujących daną dzia-

24 Û.G. Leskova, Konceptual'nye i pravovye osnovy..., s. 196. 
łalność lub zainteresowanych jej wykonywaniem ${ }^{25}$. Tradycyjny model odgórnie tworzonych struktur samorządu zawodowego funkcjonuje w Rosji, przykładowo, w odniesieniu do adwokatów. Zgodnie z art. 29 ust. 1 i 8 ustawy federalnej z dnia 31 maja 2002 roku o działalności adwokackiej i adwokaturze w Federacji Rosyjskiej ${ }^{26}$ adwokaci są zrzeszeni w izbach adwokackich na zasadzie obligatoryjnego członkostwa, przy czym w każdym podmiocie Federacji Rosyjskiej funkcjonuje tylko jedna izba adwokacka. Oddolny mechanizm tworzenia organizacji samoregulacyjnych sprawia natomiast, że ich liczba może znacząco różnić się w poszczególnych dziedzinach działalności, których wykonywanie wymaga uzyskania członkostwa w organizacji samoregulacyjnej. Według danych rosyjskiego Ministerstwa Rozwoju Gospodarczego w roku 2018 najwięcej organizacji samoregulacyjnych o obowiązkowym członkostwie funkcjonowało w sferze działalności w dziedzinie robót budowlanych - 223, podczas gdy najmniejsza liczba organizacji (2) obejmowała aktuariuszy, biegłych rewidentów i związki rewizyjne spółdzielni rolniczych ${ }^{27}$. W nauce dostrzega się, iż zbyt niska liczba organizacji samoregulacyjnych $\mathrm{w}$ danej dziedzinie działalności może prowadzić do zjawisk niepożądanych z perspektywy prawa konkurencji ${ }^{28}$.

Oddolny sposób tworzenia organizacji samoregulacyjnych — polegający na tworzeniu przez zainteresowane podmioty organizacji non-profit, która następnie, wskutek wpisania jej do rejestru organizacji samoregulacyjnych, nabywa status takowej — sprawia, że publicznoprawne znamię organizacji samoregulacyjnych o obowiązkowym członkostwie zdaje się nosić charakter transcendentny. Organizacje samoregulacyjne należy uznawać za korporacje prawa publicznego ze względu na szczególne, publicznoprawne, przydane przez prawodawcę państwowego znaczenie uzyskania członkostwa w organizacji (i pozostawania jej członkiem) dla możliwości podjęcia i wykonywania określonej działalności zawodowej. Powiązanie między członkostwem w organizacji a dopuszczalnością podjęcia i wykonywania działalności trwa zaś od momentu, gdy organizacja non-profit została wpisana do rejestru organizacji samoregulacyjnych, do momentu, gdy zostanie $\mathrm{z}$ tego rejestru wykreślona (na przykład w sytuacji, gdy przestanie spełniać ustawowe warunki posiadania statusu organizacji samoregulacyjnej). Organizacja może być zatem postrzegana jako korporacja prawa publicznego tylko w obrębie wskazanego powyżej okresu.

25 T.V. Zakupen', Osobennosti pravovogo regulirovaniâ deâtel'nosti samoreguliruemyh organizacij v predprinimatel'skih pravootnošeniâh, „Bezopasnost' biznesa” 2011, nr 1, s. 5.

${ }^{26}$ Federal'nyj zakon ot 31.05.2002 N 63-FZ ,Ob advokatskoj deâtel'nosti i advokature v Rossijskoj Federacii”.

27 Ministerstvo Èkonomičeskogo Razvitiâ Rossijskoj Federacii, op. cit., s. 217. Łączna liczba organizacji o obowiązkowym członkostwie wynosiła 627, podczas gdy łączna liczba organizacji o dobrowolnym członkostwie - 424.

28 Zob. np. A. Polškova, N. Mamatenko, Dvojstvennost' problemy členstva v samoreguliruemoj organizacji, [w:] Problemy razvitiâ samoreguliruemyh organizacij v predprinimatel'skoj deâtel'nosti v Rossijskoj Federacii, red. A.È. Zaharova, Orenburg 2020, s. 111-115. 


\section{Podsumowanie}

Instytucja samoregulacji działalności gospodarczej i zawodowej, unormowana w prawie rosyjskim, cechuje się wyraźną tożsamością prawną, odznaczając się wszakże pewnymi odmiennościami $\mathrm{w}$ obszarach funkcjonowania organizacji samoregulacyjnych o obowiązkowym i dobrowolnym członkostwie. Istotą instytucji samoregulacji jest ukształtowanie, autonomicznej względem regulacji państwowej, sfery regulacji działalności gospodarczej i zawodowej, która obejmuje normy i zasady podejmowania i wykonywania działalności ustanawiane w ramach organizacji samoregulacyjnej, adresowane do członków tej organizacji. Podmioty działalności gospodarczej i zawodowej, uzyskując członkostwo w organizacji samoregulacyjnej, przyjmują zatem na siebie obowiązek stosowania się do unormowań funkcjonujących w obrębie danej organizacji samoregulacyjnej. Podjęcie decyzji o ubieganiu się o członkostwo w organizacji samoregulacyjnej może być uwarunkowane przesłankami natury ekonomicznej i prawnej. Przesłanki ekonomiczne, związane — ogólnie rzecz ujmując — z dążeniem do polepszenia przez podmiot działalności gospodarczej lub zawodowej własnej pozycji rynkowej, mogą skłaniać do ubiegania się o przyjęcie do organizacji samoregulacyjnej funkcjonującej na zasadzie dobrowolności członkostwa. W przypadku niektórych dziedzin działalności przyjęcie do organizacji samoregulacyjnej stanowi jednak prawny wymóg podjęcia danej działalności, co sprawia, że podmioty zainteresowane wykonywaniem tej działalności są zobowiązane do uzyskania członkostwa w organizacji wskutek decyzji prawodawcy państwowego o ograniczeniu dostępu do wykonywania danej działalności. W tych okolicznościach przyjęcie podmiotu do organizacji samoregulacyjnej stanowi działanie władcze, uprawniające podmiot do podjęcia działalności uprzednio dla niego niedostępnej, zgodnie z warunkami wyznaczonymi przez prawodawcę państwowego w sposób odpowiadający potrzebie urzeczywistniania interesu publicznego. Realizowanie przez organizacje samoregulacyjne tego działania (to jest przyjmowania do organizacji, z którym - mocą decyzji prawodawcy państwowego - powiązane jest uzyskanie uprawnienia do wykonywania danej działalności) pozwala uznać je za podmioty wykonujące funkcje publicznoprawne. Właściwe będzie zarazem określenie ich mianem korporacji publicznoprawnych, w związku z okolicznością, że zrzeszają one - na zasadzie obligatoryjnego członkostwa — podmioty wykonujące działalność gospodarczą lub zawodową określonego rodzaju. Słuszności konstatacji o publicznoprawnym statusie organizacji samoregulacyjnych o obowiązkowym członkostwie nie niweczy przy tym okoliczność, że powstają one w rezultacie autonomicznie inicjowanych czynności podmiotów działalności gospodarczej i zawodowej, nie zaś wskutek działań organów władzy publicznej. Okoliczność ta sprawia natomiast, że przypisywane organizacjom znamię publicznoprawności ma charakter transcendentny, to jest ograniczony do okresu, w którym członko- 
stwo w organizacji non-profit obdarzonej statusem organizacji samoregulacyjnej wywołuje skutek w postaci władczego dopuszczenia do podjęcia $\mathrm{i}$ wykonywania określonej działalności.

\section{Bibliografia}

Banaszak B., Prawo konstytucyjne, Warszawa 2008.

Čatuev F.U., Vzaimodejstvie gosudarstva i samoreguliruemyh organizacij na investicionnom rynke, Moskwa 2007.

Domańska A., Konstytucyjne podstawy ustroju gospodarczego Polski, Warszawa 2001.

Eršova I.V., Samoregulirovanie predprinimatel'skoj deâtel'nosti, [w:] Predprinimatel'skoe pravo, red. I.V. Eršova, Moskwa 2017.

Gračev D.O., Pravila samoreguliruemyh organizacji, „Zakony Rossii. Opyt, analiz, praktika” 2009, nr 2.

Gračev D.O., Pravovoj status samoreguliruemyh organizacij, Moskwa 2008.

Lanskov P.M., Mehanizm regulirovaniâ finansovogo rynka i ego infrastruktury, Moskwa 2005.

Leskova Û.G., Konceptual'nye i pravovye osnovy samoregulirovaniâ predprinimatel'skih otnošenij, Moskwa 2013.

Małecki W., Metoda promocji jako typ metody regulacji, „Prawo” 323, 2017.

Małecki W., Policja gospodarcza w prawie gospodarczym, Warszawa 2019.

Ministerstvo Èkonomičeskogo Razvitiâ Rossijskoj Federacii, O sostoânii razvitiâ samoregulirovaniâ predprinimatel'skoj i professional'noj deâtel'nosti v Rossijskoj Federacii, Moskwa 2019.

Polškova A., Mamatenko N., Dvojstvennost' problemy členstva v samoreguliruemoj organizacii, [w:] Problemy razvitiâ samoreguliruemyh organizacij v predprinimatel'skoj deâtel'nosti v Rossijskoj Federacii, red. A.È. Zaharova, Orenburg 2020.

Salin P.B., Stanovlenie i razvitie instituta samoreguliruemoj organizacii v Rossijskoj Federacii (teoretiko-pravovoe issledovanie), Petersburg 2009.

Valitova A., Uzbekov T., Samoreguliruemye organizacii na rynke cennyh bumag: za i protiv obâzatel'nogo členstva, [w:] Problemy razvitiâ samoreguliruemyh organizacij v predprinimatel'skoj deâtel'nosti v Rossijskoj Federacii, red. A.È. Zaharova, Orenburg 2020.

Zakupen' T.V., Osobennosti pravovogo regulirovaniâ deâtel'nosti samoreguliruemyh organizacij $v$ predprinimatel'skih pravootnošeniâh, „Bezopasnost' biznesa” 2011, nr 1.

Zinčenko S.A., Galov V.V., Samoreguliruemye organizacii v zakonodatel'stve Rossii: problemy i rešeniâ, [w:] Korporacii i učreždeniâ, red. M.A. Rožkova, Moskwa 2007.

\section{Self-Regulation of Economic and Professional Activity: Self-Regulatory Organizations in Russian Law}

\footnotetext{
Summary

Self-regulation of economic and professional activity consists of creating and controlling the observance of norms regulating a given activity by entities performing this activity. In Russian
} 
law, self-regulation is carried out primarily through the functioning of self-regulatory organizations, associating entities of specific economic or professional activity. Self-regulatory organizations function as voluntary and mandatory membership organizations. In certain areas of economic and professional activity, obtaining membership in a self-regulatory organization, subject to the fulfillment of certain conditions is a legal requirement to undertake a given activity. For this reason, self-regulatory organizations with mandatory membership should be considered public law corporations. The public-law nature of these organizations is transcendent due to the bottom-up way of their creation.

Keywords: economic activity, professional activity, self-regulation, self-regulatory organization, Russian law. 